\title{
"The investment model of fixed assets renovation in the agricultural industry: case of Ukraine"
}

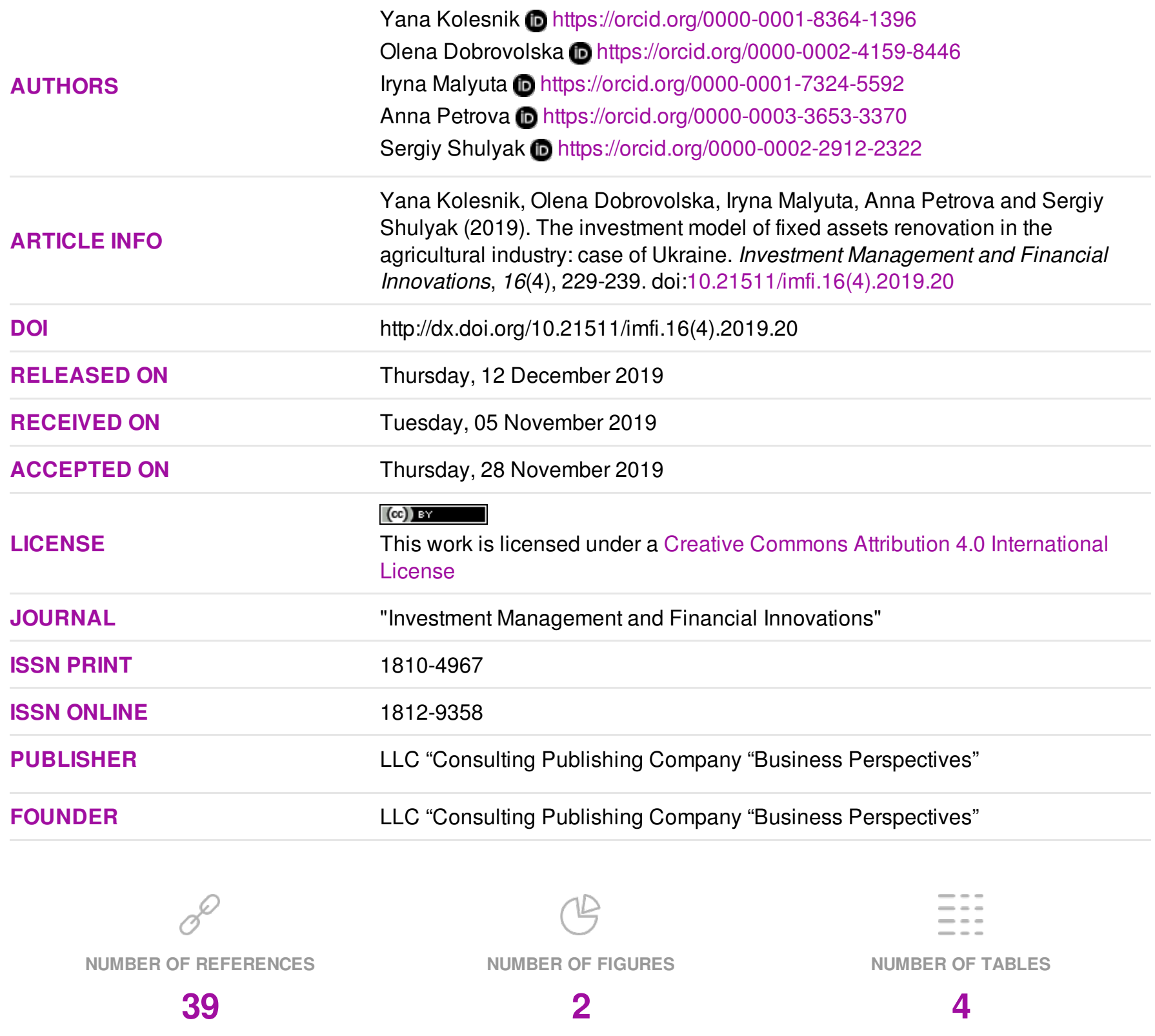

(C) The author(s) 2023. This publication is an open access article. 


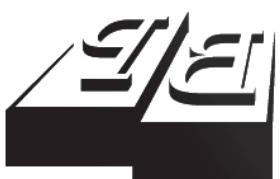

BUSINESS PERSPECTIVES

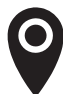

LLC "CPC "Business Perspectives" Hryhorii Skovoroda lane, 10, Sumy, 40022, Ukraine

www.businessperspectives.org

Received on: $5^{\text {th }}$ of November, 2019 Accepted on: $28^{\text {th }}$ of November, 2019

(C) Yana Kolesnik, Olena Dobrovolska, Iryna Malyuta, Anna Petrova, Sergiy Shulyak, 2019

Yana Kolesnik, Ph.D. in Economics, Associate Professor, Finance, Banking and Insurance Department, Dnipro State University of Agriculture and Economics, Ukraine.

Olena Dobrovolska, Doctor of Economics, Professor ofFinance, Banking and Insurance Department, Dnipro State University of Agriculture and Economics, Ukraine.

Iryna Malyuta, Ph.D. in Economics, Associate Professor, Department of International Economics, International Humanities University, Ukraine.

Anna Petrova, Ph.D. in Economics, Associate Professor, Department of International Economics, International Humanities University, Ukraine.

Sergiy Shulyak, Ph.D. in Economics, Associate Professor, Department of International Economics, Moldova State University, Moldova.

\section{(c) (i)}

This is an Open Access article, distributed under the terms of the Creative Commons Attribution 4.0 International license, which permits unrestricted re-use, distribution, and reproduction in any medium provided the original work is properly cited.
Yana Kolesnik (Ukraine), Olena Dobrovolska (Ukraine), Iryna Malyuta (Ukraine), Anna Petrova (Ukraine), Sergiy Shulyak (Moldova)

\section{THE INVESTMENT MODEL OF FIXED ASSETS RENOVATION IN THE AGRICULTURAL INDUSTRY: CASE OF UKRAINE}

\begin{abstract}
The present state of the financial market in Ukraine determines a lack of funding for agricultural enterprises. The research aims to find internal sources of funding for the reproduction of fixed assets for agricultural enterprises. The calculation of the depreciation return index is a component of financial analysis of the efficient renovation investment use. It allows controlling its targeting and influence on enterprises in a financial aspect in order to provide a stable position of the enterprise`s investor.

Implementation of economic and mathematical modeling using correlation and regression analysis verified a tight correlation between gross profit margins in agriculture and depreciation returns. For this purpose, general indexes were formed that is the primary value of fixed assets at the end of the year; the extent of their depreciation, depreciation and residual value of fixed assets at the end of the year, the average annual value of fixed assets, annual income, investment return and calculated gross profit and depreciation during 2001-2016 were determined.
\end{abstract}

The results of the calculations showed that the funds saved through depreciation (renovation investments), and retained earnings are the financial resources for continuous renovation of fixed assets of agricultural enterprises. Also, attraction to internal reserves should have an impact on the increase of the agricultural enterprises' profitability and should facilitate the increase of production volumes due to the implementation of innovations.

\section{Keywords}

money pool, depreciation, depreciation return, renovation, investing

\section{JEL Classification O11, O13, Q14}

\section{INTRODUCTION}

Agriculture is considered to be a priority sector of the economy and a prerequisite for economic and food security in Ukraine. Although Ukraine's investment attractiveness remains low, the agricultural sector still attracts foreign investors since they are enticed by the potential of Ukraine as an agricultural state with fertile black soil. At the same time, there are numerous restraining factors hindering the ability to obtain foreign funding to the required extent and under favorable conditions. Among these are as follows: lack of a land market, imperfection of the legislative base, corruption of the authorities at all levels, complex tax system, high state-level debt. Commercial bank loans are expensive and do not always offer abundant resources, and government support is provided only in selected areas.

Nowadays, the question of finding its financial reserves for increasing the outputs becoming more crucial. The implementation of renovation investment is increasing day by day. But there is a problem, as a large part of the renovation investment is the basis for covering the shortfall 
in working capital, which negatively affects the enterprise financial performance, including profit. In the developed countries, renovation investment is an effective financial tool for increasing the productive capacity. However, there are still unresolved issues regarding the effectiveness of its implementation.

It is worth noting that nowadays, there are no any methods of qualitative assessment of renovation investment so it is efficient to use depreciation return index, which will allow evaluating the efficiency of implementation of renovation investment and its purposeful use. An investment model proposed and investigated in the article proves a direct relationship between renovation investment, i.e., its qualitative component (depreciation return) and profit. As a result, it will allow determining the impact strength of renovation investment on the financial results of the agricultural sector of Ukraine and confirm the relevance of intensification of renovation investment to ensure the gradual sustainable and qualitative economic development of the industry under the current conditions.

\section{LITERATURE REVIEW}

The problem of renovation investment implementation in the process of innovative reproduction of agricultural sector attracts the scientists from different countries. At the same time, the issues considered in their research are very similar, i.e., the study of renovation investment from the point of view of using the depreciation in accounting rather than from the financial or investment perspective as well as from the perspective of its efficient utilization and targeting.

The issues of investing in different economic sectors and from different viewpoints were studied in many works, e.g., Kolodiziev, Tyschenko, and Azizova (2017) analyzed the types of investment projects bank financing based on the state and private partnership. Using the structural modeling, Katan, Dobrovolska, and Recio Espejo (2018) define the necessary amount of financing for agrarian sector through the budget financing, bank lending, and agroinsurance. Kharaishvili, Gechbaia, and Mamuladze (2018) study the problems of financing and increasing the competitiveness level of the vegetable industry in Georgia. Yevdokimov, Chygryn, Pimonenko, and Lyulyov (2018) consider such a direction of investing in the Ukrainian agrarian sector as biogas production. Here the sugar plants, poultry farms, and the enterprises, dealing with growing and processing of corn and sunflower, have the highest potential of biogas production.

Sigidov, Rybyantseva, Adamenko, and Yarushkina (2016) express their opinions on the identification of renovation investment and depreciation. The authors focus on the fact that the latter is a complex economic category, the essence of which is appeared in duality. It is not only an element of expenditure but also source of reproduction of fixed and intangible assets. For that reason, in their opinion, a methodological study of depreciation nature, its classification, principles, and functions identification is relevant.

Sokolova (2008) pays particular attention to renovation investments since in developed countries depreciation policy is one of the main instruments of economic growth. At present renovation investment including general investment accounts for over $70 \%$.

Mukasheva et al. (2018)considered a burning issue in the context of finding the sources of investment funding for the agricultural sector of the economy, i.e., renovation investment in the form of depreciation which should become a major source of investment potential since the resources involved are expensive and limited.

Nurullin, Subaeva, and Aleksandrova (2018) are confident that the quality of management decisions is mainly determined by the use of economic and mathematical methods of research in the current economic conditions.

The use of correlation and regression analysis enabled to obtain a multifactor model of fixed asset efficiency by agricultural enterprises in the Ulianivsk region. Analysis of the colors of maps and cluster profiles showed that the most significant indicators of asset return, which are the main indicators of effective management of fixed assets, 
are considered to be a degree of fixed assets renewal, the value of current assets per 100 rubles of fixed capital assets, a share of the active part of the funds, the degree of depreciation of fixed assets (p. 265).

Mayevsky, Malkov, and Rubinstein (2018) suggested the Shifting Mode of Reproduction (SMR) mod$\mathrm{el}$, which is used as a tool to analyze some of the dynamic processes specific for the United States in 1947-2010. The SMR model shows that despite the serious difficulties in 2009-2015, the ways of increasing the share of fixed capital growth in Russian economy were identified.

Nurullin, Subaeva, Nurullin, and Aleksandrova (2018) raise a question regarding the quality management of fixed assets reproduction in agriculture. They suggest a multifactor model of fixed assets efficiency according to the clustering rules. The clusters analysis carried out by the scientists showed that the most significant indicators of fixed assets effective management are the indicators of the fixed assets renovation rate, the share of the active part of funds, the degree of fixed assets depreciation. At the same time, the issue of efficient renovation investment use is not raised, which is the main source in the process of fixed assets renovation and modernization.

Pronyaeva (2016) considers the structure of fixed assets reproduction sources in agricultural enterprises and provides an estimate of the depreciated investment resources. The author refers them to the renovation investment. The author thinks that the depreciation plays a key position in the structure of investment funding sources since depreciation charges are aimed at updating and modernization of fixed capital in agriculture. And it allows tracing the targeted use of accumulated funds.

There is a tendency of decreasing investment activity, which preconditions a rational choice of the appropriate investment source alongside the limited machinery availability for the agricultural sector and the high intensity of its use. Therefore, Smoliy, Zagorodniuk, and Maliuga (2017) suggest a model for making ideal decisions in the investment process with limited financial resources. The minimum cost of the project in terms of investment formed by external and internal sources in the form of depreciation allowances was chosen as one of the optimization criteria. Thus, renovation investment can be used to modernize fixed assets of agricultural enterprises taking into account their performance and cultivated areas.

Alkhateeb, Ajina, George, and Mahmood (2017) consider the benefits of renovation investmentimplementation to improve the agricultural trade balance in the long run.

Golas (2016) conducts the research based on a system of labor profitability and factor analysis indexes where depreciation allowances (renovation investment) are one of the factors that lead to favorable changes in labor profitability in the agricultural sector of the economy.

Kalinowski (2017) considers depreciation allowances (renovation investment) as a major component of fixed expenditures. If a large amount of renovation investment is accumulated in an enterprise, then such a company can be characterized by high operational risks measured by operating leverage. The focus is on the economic component of renovation investment, not on the financial one.

Gómez-Lobo (2016) studies the renovation investment in terms of using the depreciation in accounting by different methods without considering the aspect of investment for the development of internal reserves for maintenance and reproduction of natural resources.

Tronin (2015) considers economic activity in terms of its components (operational, investment, and financial), which are interrelated. It is the relationship between investment and financial activity that reveals itself through the reinvestment according to the depreciation rate. It happens when the counter flow of financial resources is directed from the sphere of investment into the sphere of payments. Nowadays, there is an investment approach to renovations, but the qualitative component was not revealed by Tronin.

According to Ismail, Karim, and Basri (2016), increasing the amount of renovation investment due to the depreciation accumulated for agricultural areas by the example of Malaysia suffering from floods is a burning issue for Ukraine. Here the deprecia- 
tion on land plots is not accumulated, and its value decreases because of non-compliance with crop rotation rules. The amounts of this renovation investment could be used for restoring the land fertility.

House and Shapiro (2008) suggest resolving the issue of depreciation accumulationin terms of estimating the investment proposal elasticity. At the same time, the renovation investment elasticity in fixed assets with a sufficiently long service life is almost infinite.

Yatsukh (2018) highlights the issue of the factors that directly affect the financial support of fixed assets reproduction process of agricultural enterprises, i.e., the lack of depreciation accumulation on land which in turn leads to a renovation investment decrease.

Li and Hall (2016) consider the study of renovation investment only in the context of accounting and using depreciation in the book records, determining its norms, which vary depending on the industry.

Nechaev, Barykina, and Puchkova (2017) pay great attention to the depreciation allowances (renovation investment) as the main factor in manipulating the efficiency of fixed assets renovation.

Kosnikov, Khaibullina, Ignatskaya, Bakharev, and Pinchuk (2017) describe the renovation investment in terms of attracting investment funds. They analyze the dynamics of financial capital, which does not influence the renovation of real capital in the context of the modern development paradigm. It emphasizes the importance of enterprises innovation potential and the economy as a whole. There are also certain problems at the moment, especially in calculating the capital recovery when carrying out the economic analysis of an enterprise. The study performed by the authors mentioned above emphasizes the relevance of the problem of physical and moral obsolescence of fixed assets and determines the need for their modernization through the implementation of innovative technologies that correspond to modern technological paradigms.

Amanova et al. (2016) developed an evidentiary approach to managing a company's depreciation policy by improving the existing methods and guidelines for mobilization of depreciation instru- ments to provide a financial source for the fixed assets renovation. The authors consider the accumulation of cash depreciation expenses for their further investment into fixed assets through the management of the company's depreciation policy.

Thus, the issue of renovation investment requires serious research in the context of the financial component of renovation investment as well as the efficiency of use and target allocation of depreciation allowances. This research is relevant since the accumulated financial resources of the depreciation fund are not used properlyin Ukrainian enterprises; they are mainly used to update the enterprises' working capital.

\section{METHODS}

Depreciation return is an index that allows analyzing the need for the fixed assets reproduction of agricultural enterprises and choosing the right way for the depreciation allowances. The system of equations for calculating the index of depreciation return (formula 1) was suggested:

$$
\left\{\begin{array}{l}
D_{R O A}=D \cdot R O A, R O A>0 ; \\
D_{R O A}=\frac{D}{\overline{F A}} \cdot Q ; \\
Q=N \cdot P_{r} ; \\
P_{r}=C+P ; \\
C=C_{m}+C_{p}+C_{s e}+D+C_{o} ; \\
P_{r}=C_{m}+C_{p}+C_{s e}+C_{o}+D+P .
\end{array}\right.
$$

where $D_{R O A}$ is the depreciation return, UAH; $D$ the amount of depreciation allowances by the fixed assets per unit of production, UAH; ROA fixed assets ratio, $\overline{F A}$ - average annual cost of fixed assets, UAH; $Q$-income from sales of agricultural products, UAH; $\mathrm{N}$ - gross output, units; $P_{r}$ - unit price, $\mathrm{UAH} / \mathrm{unit}$; $C$-prime cost per unit, $\mathrm{UAH} /$ unit, $\mathrm{P}$ - profit per unit of production, $\mathrm{UAH} /$ unit, $C_{m}$ - costs per unit of production, UAH/unit, $C_{p}$ - labor costs per unit of production, UAH/unit, $D+P$ - the components of reproduction source ("pool" of agricultural enterprises); $C_{s e}$ - benefitsrelated allowances per unit of production, UAH/ unit; $C_{o}$ - other operating costs per unit of production, UAH/unit. 
Analysis of fixed assets of agricultural enterprises requires a technique of calculating the depreciation return rate. As the entity constantly makes depreciation allowances, it is also necessary to estimate their efficiency. Low efficiency ratio reduces the economic viability of the above measures. A restriction $R O A>0$ was taken into account and it indicates that the amount of income of an agricultural enterprise must exceed the value of fixed assets involved in the production process, emphasizing their efficiency and productivity.

So, in fact, the following inequality $R O A>1$ must be observed in the leading agricultural enterprise. Depreciation and profit totally are a source of developing a process of simple fixed assets reproduction and are represented in the form of internal renovation investment. It is actually a part of the coefficient of return on assets and form the "pool" of the agricultural enterprise. The calculation of the depreciation return index for economic and mathematical modeling is given in the next section.

\section{RESULTS}

The issue of morally and physically obsolete fixed assets use by agricultural enterprises remains topical in Ukraine. According to the State Statistics Service of Ukraine, the depreciation of all fixed assets in Ukraine in 2018 was $60.6 \%$, in agriculture, this indicator was $35.1 \%$. When it comes to the renovation rate, it is $4 \%$ across Ukraine and $16.6 \%$ in agriculture (State Statistics Service of Ukraine, 2016). The importance of enhancing the production efficiency and improving the financial performance determines the implementation of innovative developments and the creation of new generation technology.

This issue is of particular relevance for agricultural enterprises. Here the innovative reproduction of fixed assets is not only ensured by their competitiveness but also has a direct impact on solving the problem of food and consumer security of the state as a whole. To solve this problem, organizational and methodological foundations of agricultural enterprises on an innovative basis were suggested (Figure 1).
The implementation of this model will help agricultural enterprises effectively control the implementation of the latest technologies in production. Fixed assets reproduction is an integral part of this model, as technical equipment directly affects the agricultural enterprises' operation. Agricultural enterprises face a problem of the finding funding sources for fixed assets reproduction on an innovative basis with both internal and external investment (Figure 1).

Nowadays, not all agricultural enterprises can obtain external funding sources, taking into account the peculiarities of the production process and the fact that at the initial stage, the enterprises are studied in terms of their solvency and competitiveness in their industry. The key point is that an external investment may not always ensure full reproduction and expected economic effect since the attracted capital is predominantly "selective" in nature. That is, an enterprise receives the funds at the time of acquiring certain fixed assets, and to attract funds at the next reproduction stage, it will have to wait for a certain period of time. It is important to take into consideration that when applying to a particular financial institution, a company cannot be sure of receiving the required amount in full. Typically, a certain part of the loan is agreed, taking into account the pledge, financial position of the enterprise, and the associated potential risks. On the other hand, the need for financial institutions as permanent "donors" of financial sources contributes to increasing the financial dependence of an agricultural enterprise on external funding sources, which significantly affects the company's further economic development. The resources attracted are very expensive and actually contribute to an increase in the expenditure of agricultural enterprises.

Thus, within the internal funding sources of the fixed assets reproduction, it is advisable to form a special fund called the "pool" of an agricultural enterprise. This pool will accumulate not only the funds in the form of depreciation allowances and retained earnings but also the funds saved on account of budgetary allocations in the form of financial support and assistance from the state, budget subsidies, and cheaper loans in the form of repayment of a certain part of the received amount of the commercial credit (Figure 1). 
Source: Developed by the authors.

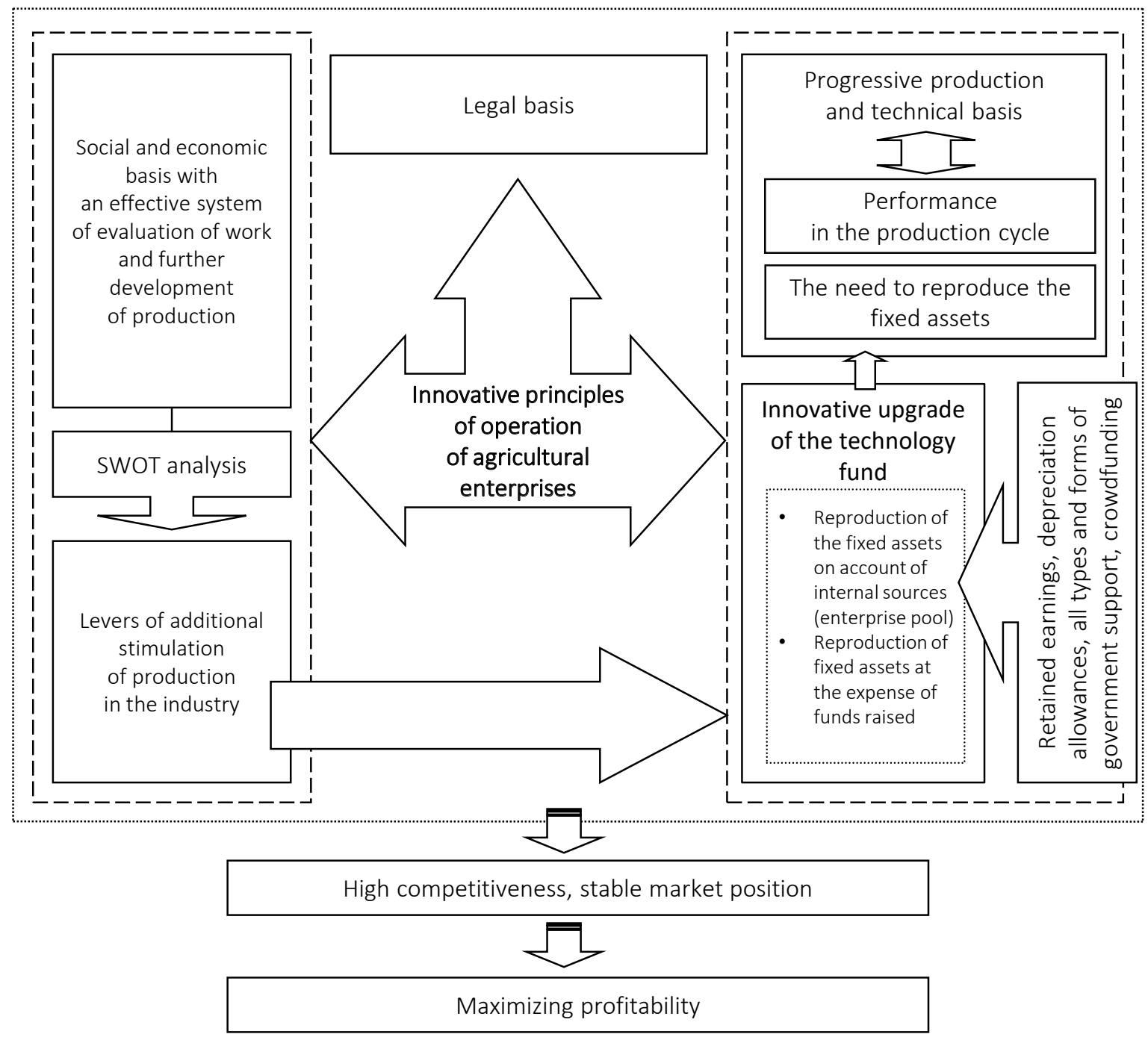

Figure 1. Organizational and methodological principles of the performance of agricultural enterprises on an innovative basis

As internal financial resources, i.e., renovation investment are becoming more interesting, it is necessary to study the impact of the renovation investment index on the financial result. For this purpose, it is proposed to build an investment model of the renovation investment impact on the financial result of the agricultural sector. For this reason, the general indexes of the fixed assets value of the industry were formed to conduct the study of income and depreciation; and the coefficients of return on assets and depreciation (Formula 1) based on the data obtained were calculated (Table 1).

Analysis of the data for the period of the study shows that the amount of depreciation in agriculture is gradually increasing. It is possible to up- grade the fixed assets at the expense of own funds, which is reflected in the improvement of the performance indexes of activity, i.e.,income (gross domestic product of the Ukrainian agricultural sector) and gross profit.

At the second stage, the input data set for the investment model and the calculation of basic indicators were formed (Table 2).

The investment model of the renovation investment impact on the financial result of the agricultural sector is based on correlation and regression analysis. Correlation analysis is used to determine the strength and area of influence of one factor on another. In this case, $X$ and $Y$ are the depreciation 
Table 1. Key indexes of the agricultural industry for the study

Source: Authors' calculations based on State Statistics Service of Ukraine (2011, 2016, 2018).

\begin{tabular}{|c|c|c|c|c|c|c|c|}
\hline Year & $\begin{array}{l}\text { Primary cost } \\
\text { of fixed assets } \\
\text { at end of the } \\
\text { year, mln UAH }\end{array}$ & $\begin{array}{c}\text { The } \\
\text { degree of } \\
\text { wear, } \%\end{array}$ & $\begin{array}{c}\text { Depreciation, } \\
\text { mln UAH }\end{array}$ & $\begin{array}{c}\text { Primary cost of } \\
\text { fixed assets at } \\
\text { end of the year, } \\
\text { mln UAH }\end{array}$ & $\begin{array}{l}\text { Average annual } \\
\text { cost of fixed } \\
\text { assets, mln UAH }\end{array}$ & $\begin{array}{c}\text { Revenue, mln } \\
\text { UAH }\end{array}$ & $\begin{array}{l}\text { Fund } \\
\text { return }\end{array}$ \\
\hline 2001 & $93,392.00$ & 49.60 & $46,322.43$ & $47,069.57$ & $70,230.78$ & $29,421.00$ & 0.42 \\
\hline 2002 & $86,192.00$ & 49.30 & $42,492.66$ & $43,699.34$ & $64,945.67$ & $29,418.00$ & 0.45 \\
\hline 2003 & $77,979.00$ & 50.40 & $39,301.42$ & $38,677.58$ & $58,328.29$ & $29,059.00$ & 0.50 \\
\hline 2004 & $75,447.00$ & 51.10 & $38,553.42$ & $36,893.58$ & $56,170.29$ & $37,258.00$ & 0.66 \\
\hline 2005 & $76,034.00$ & 52.20 & $39,689.75$ & $36,344.25$ & $56,189.13$ & $40,542.00$ & 0.72 \\
\hline 2006 & $75,511.00$ & 48.20 & $36,396.30$ & $39,114.70$ & $57,312.85$ & $41,006.00$ & 0.72 \\
\hline 2007 & $78,978.00$ & 46.20 & $36,487.84$ & $42,490.16$ & $60,734.08$ & $47,417.00$ & 0.78 \\
\hline 2008 & $95,880.00$ & 45.70 & $43,817.16$ & $52,062.84$ & $73,971.42$ & $65,148.00$ & 0.88 \\
\hline 2009 & $103,187.00$ & 39.60 & $40,862.05$ & $62,324.95$ & $82,755.97$ & $65,758.00$ & 0.79 \\
\hline 2010 & $113,388.00$ & 40.80 & $46,262.30$ & $67,125.70$ & $90,256.85$ & $82,948.00$ & 0.92 \\
\hline 2011 & $118,019.00$ & 32.60 & $38,474.19$ & $79,544.81$ & $98,781.90$ & $109,961.00$ & 1.11 \\
\hline 2012 & $137,640.00$ & 34.60 & $47,623.44$ & $90,016.56$ & $113,828.30$ & $113,245.00$ & 0.99 \\
\hline 2013 & $156,013.00$ & 35.80 & $55,852.65$ & $100,160.35$ & $128,086.70$ & $132,354.00$ & 1.03 \\
\hline 2014 & $171,392.00$ & 38.80 & $66,500.10$ & $104,891.90$ & $138,142.00$ & $161,145.00$ & 1.17 \\
\hline 2015 & $210,169.00$ & 38.90 & $81,755.74$ & $128,413.26$ & $169,291.10$ & $239,806.00$ & 1.42 \\
\hline 2016 & $270,467.00$ & 37.30 & $100,884.19$ & $169,582.81$ & $220,024.90$ & $279,701.00$ & 1.27 \\
\hline
\end{tabular}

Table 2. Dynamics of gross profit indexes of the investigated industry and depreciation return for 2001-2016

Source: Authors' calculations and statistics (State Committee on Statistics of Ukraine $(2011,2016,2018)$ ).

\begin{tabular}{|c|c|c|}
\hline Year $(t)$ & Gross profit (loss) $\left(y_{t}\right)$, mln UAH & Depreciation return $\left(x_{t}\right)$, mln UAH \\
\hline 2001 & $23,567.00$ & $19,405.34$ \\
\hline 2002 & $24,085.00$ & $19,247.61$ \\
\hline 2003 & $24,306.00$ & $19,579.86$ \\
\hline 2004 & $31,903.00$ & $25,572.65$ \\
\hline 2005 & $34,492.00$ & $28,637.24$ \\
\hline 2006 & $34,298.00$ & $26,040.70$ \\
\hline 2007 & $37,959.00$ & $28,487.20$ \\
\hline 2008 & $53,746.00$ & $38,590.58$ \\
\hline 2009 & $51,861.00$ & $32,469.04$ \\
\hline 2010 & $65,357.00$ & $42,516.06$ \\
\hline 2011 & $87,509.00$ & $42,828.30$ \\
\hline 2012 & $86,330.00$ & $47,379.41$ \\
\hline 2013 & $100,878.00$ & $57,713.44$ \\
\hline 2014 & $128,518.00$ & $77,573.52$ \\
\hline 2015 & $203,286.00$ & $115,809.48$ \\
\hline 2016 & $238,555.00$ & $128,246.43$ \\
\hline Average value of the indicator & $76,665.63$ & $46,881.05$ \\
\hline
\end{tabular}

return and gross profit of the Ukrainian agricultural sector; $n=16$. The results of the correlation analysis are provided in Table 3.

The calculations result is $r_{X Y}=0.9944$. The value of the sample correlation coefficient indicates a tight correlation. It is direct because $r_{X Y}>0$. Thus, as depreciation return increases, the gross profit of the Ukrainian agricultural sector also grows. The correlation coefficient should be checked for significance. The calculations showed that the level of weight $p=4.56 \cdot 10^{-16}$ (probability of a type one error when the true hypothesis is rejected), and, thus, $p<0.001$ norm is fulfilled indicating a very high significance of the calculated correlation coefficient. The correlation between gross profit and depreciation is direct and very strong since the hypothesis $H_{0}$ of unreliability of the correlation coefficient does not maintain the inequality $\left|t_{\tilde{N} O}\right|<t_{p}(n-2)$. 
Table 3. Results of correlation analysis

Source: Calculated by the authors.

\begin{tabular}{l|c|c|c}
\hline \multirow{2}{*}{$\begin{array}{c}\text { Correlation } \\
\text { coefficient }\end{array}$} & \multicolumn{2}{|c}{ Indicators to test the hypothesis about the reliability of the correlation coefficient } \\
\cline { 2 - 4 } & $t_{p}(n-2)$ & $\left|t_{C T}\right|$ & level of significance $p$ \\
\hline 0.9944 & 2.145 & 35.20 & $4.56 \cdot 10^{-16}$ \\
\hline
\end{tabular}

Regression analysis was performed; since there is one independent variable, then the regression is univariate (one factor). The graphical method was used to determine the type of index dependence (Figure 2).

There is a linear dependence between the gross profit of the agricultural sector and the depreciation return (regression equation - formula 2).

$$
\hat{y}_{t}=1.9299 x_{t}-13,809 \text {. }
$$

The calculation of the agricultural sector gross profit and depreciation return (formula 2) as well as the indexes for determining the accuracy of the model are systematized and shown in Table 4 . The values of the determination coefficient and the standardized determination coefficient are high and similar to each other. They are 0.9888 and 0.9880 , respectively.

The $H_{0}$ hypothesis is implemented to check the significance of the impact of $x_{t}$ on $y_{t}$, according to which all independent variables do not affect the dependent variable in the following inequality:

$$
F_{\tilde{N} \dot{O}}<F_{p}\left(q_{1}, q_{2}\right),(3)
$$

where $F_{p}\left(q_{1}, q_{2}\right)$ is a $100 \%$ point of $F$ - distribution with the probability that a random variable $F>F_{p}\left(q_{1}, q_{2}\right)$ is equal to $p$.
$H_{0}$ hypothesis on the absence of influence of an independent variable on the dependent one was not confirmed because $F_{C T}>F_{p}\left(q_{1} q_{2}\right)$, which is contrary to inequality(3). Therefore, all the above analysis of the data indicates the high accuracy of the model.

Consequently, the investment model of the renovation investment impact on the financial result of the agricultural sector of Ukraine is economically and statistically proven. The main confirmation is the very strong direct correlation between the gross profit indexes of the agricultural sector of Ukraine and the depreciation return. The visualization of the correlation is shown in Figure 2. It is worth noting that obviously the impact of technical equipment on profit is due to the so-called third parameter. That is, the speed and quality of work related to production (crop production, animal breeding, etc.) and the need to involve manual labor or outsourced organizations, which generally form a large part of the cost, depend on the availability and level of modernization of the fixed assets.

Currently, the main source of the funds accumulation for the process of fixed assets reproduction in the agricultural sector must be the innate potential of the enterprise; i.e., the funds saved on account of depreciation return (renovation investment) and profit, which will increase the capacity of the industry and its profitability.

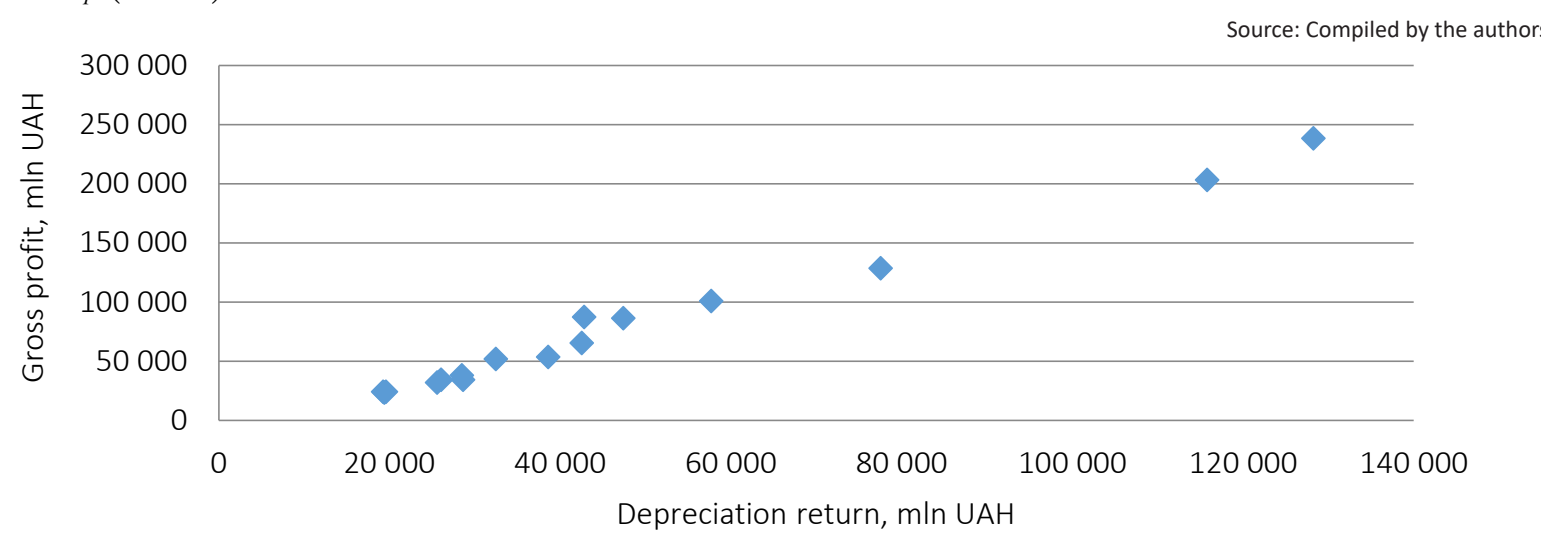

Figure 2. Dependence between agricultural industry gross profit and depreciation return 
Table 4. Calculation of the gross profit in the agricultural sector of Ukraine and the accuracy indexes of the model

Source: Calculated by the authors based on State Committee on Statistics of Ukraine $(2011,2018)$.

\begin{tabular}{|c|c|c|}
\hline Years, $t$ & Gross profit $\left(\hat{y}_{t}\right), \mathrm{mln} \mathrm{UAH}$ & $\begin{array}{l}\text { Deviation of the actual value from the value } \\
\text { calculated by regression, mln UAH } \\
\qquad \hat{\varepsilon}_{t}=y_{t}-\hat{y}_{t}\end{array}$ \\
\hline 2001 & $23,641.37$ & -74.37 \\
\hline 2002 & $23,336.96$ & 748.04 \\
\hline 2003 & $23,978.17$ & 327.83 \\
\hline 2004 & $35,543.66$ & $-3,640.66$ \\
\hline 2005 & $41,458.02$ & $-6,966.02$ \\
\hline 2006 & $36,446.95$ & $-2,148.95$ \\
\hline 2007 & $41,168.44$ & $-3,209.44$ \\
\hline 2008 & $60,666.97$ & $-6,920.97$ \\
\hline 2009 & $48,853.00$ & $3,008.00$ \\
\hline 2010 & $68,242.74$ & $-2,885.74$ \\
\hline 2011 & $68,845.33$ & $18,663.67$ \\
\hline 2012 & $77,628.52$ & $8,701.48$ \\
\hline 2013 & $97,572.16$ & $3,305.84$ \\
\hline 2014 & $135,900.14$ & $-7,382.14$ \\
\hline 2015 & $209,691.71$ & $-6,405.71$ \\
\hline 2016 & $233,693.79$ & $4,861.21$ \\
\hline
\end{tabular}

Accuracy indexes of the developed regression model

\begin{tabular}{l|c|c|c|c}
\hline $\begin{array}{c}\text { Characteristics of } \\
\text { accuracy }\end{array}$ & Determination factor $r^{2}$ & $\begin{array}{c}\text { Standardized coefficient } \\
\text { of determination } r_{n}^{2}\end{array}$ & $F_{p}\left(q_{1} q_{2}\right)$ & $F_{C T}$ \\
\hline $\begin{array}{l}\text { Values according to the } \\
\text { developed regression model }\end{array}$ & 0.9888 & 0.9880 & 4.60 & 616.36 \\
\hline
\end{tabular}

\section{CONCLUSION}

Considering the ongoing process of economic turbulence in Ukraine, the agricultural sector cannot stay in a state of indifference. It needs to be reproduced using the innovative methods that are reflected both in the financial sphere (innovative re-equipment of the industry) and the use of innovative approaches to management and attracting the innovative forms, types of financial resources. It is necessary to search for own investment reserves in the form of special monetary fund called the "pool" adhering to the conditions of intended use. Cash pools accumulate funds in the form of retained earnings and depreciation which are not always used for their intended purpose. In most cases they are intended to cover working capital shortages. Also a significant component of cash "pools" are the funds saved through budgetary allocations in the form of providing financial support from the state and cheaper loans in the form of repayment of a portion of interest for using commercial credit. The innovative side of cash pool formation is through crowdfunding taking into account crowdinvesting.

The investment model of the renovation investment impact on the financial result of the agricultural sector confirms the need to focus specifically on its own financial resources in the conditions of economic instability and difficulty in obtaining the attracted financial resources. Since, there is a direct correlation between the depreciation return indexes (qualitative component of renovation investment) and the industry's gross profit. Depreciation is one of the components of the investment model. This index is proposed for a more complete and effective analysis of the depreciation policy, the targeted use of depreciation and the analysis of available fixed assets used in agriculture. 


\section{REFERENCES}

1. Alkhateeb, T. T., Ajina, A. S., George, S., \& Mahmood, H. (2017). Egyptian intra agriculture trade with GAFTA members: Reilly's law of retail gravitation and marketing effects. International Journal of Economic Research, 14(9), 137-147. Retrieved from https://www.researchgate.net/ publication/319479146_Egyptian_intra_agriculture_trade_ with_GAFTA_members_Reilly's_ law_of_retail_gravitation_and_ marketing_effects

2. Amanova, G., Saparbayeva, S., Akimova, B., Dairabayeva, A., Kazhmukhametova, A., Saduakassova, K., \& Tuleshova, G. (2016). Methodological aspects of depreciation accounting and analysis of the use of the depreciation policy. Journal of Advanced Research in Law and Economics, 7(3), 483-493. Retrieved from https://journals. aserspublishing.eu/jarle/article/ view/179

3. Buffett, W. (2011). Invest Like a Billionaire: If You Are Not Watching the Best Investor in the World, Who Are You Watching? Retrieved from https://www. amazon.com/Invest-Like-Billionaire-Watching-Paperback/dp/ B00FKZG3M4

4. Dovbish, G. V. (2008). Amortyzatsiia osnovnykh zasobiv: filosofiia obliku narakhuvannia i vykorystannia [Depreciation of fixed assets: the philosophy of accounting for accrual and use]. Ekonomika: problemy teorii $i$ praktyky-Economics: problems of theory and practice, 213, 994-1002 (in Ukrainian).

5. Eisner, R. (2008). Accelerated amortization, growth, and net profits. The Quarterly Journal of Economics, 66(4), 533-544. https:// doi.org/10.2307/1882103

6. Gaidutsky, A. P. (2004). Superechnosti investytsiinykh procesiv $\mathrm{v}$ ahrarnomu sektori Ukrainy [Contradictions of investment processes in the agrarian sector of Ukraine]. Statystyka Ukrainy - Statistics of Ukraine, 3, 61-66 (in Ukrainian).
7. Golas, Z. (2016). The level and determinants of work profitability changes in the Czech and polish agricultural sector in the years 2004-2014. Agricultural Economics (Czech Republic), 62(7), 334-344. https://doi. org/10.17221/159/2015-AGRICECON

8. Gómez-Lobo, A. (2001). Sustainable development and natural resource accounting in a small open economy: a methodological clarification. Estudios de Economía, 28(2), 203-216. Retrieved from https:// www.semanticscholar.org/ paper/Sustainable-development-and-natural-resourcein-a-a-G\%C3\%B3mez-Lobo/ a4163e541a3dece75b03f955a24eaf954bb46ae 1

9. Gorodyanska, L. V. (2009). Amortyzatsiina polityka ta napriamy vidtvorennia finansovo-ekonomichnykh resursiv u bukhhalterskomu obliku [Depreciation policy and directions of reproduction of financial and economic resources in accounting]. Finansy Ukrainy - Finance of Ukraine, 11, 112-121 (in Ukrainian).

10. House, C. L., \& Shapiro, M. D. (2008). Temporary Investment Tax Incentives: Theory with Evidence from Bonus Depreciation. American Economic Review, 98(3), 737-768. https://doi.org/10.1257/ aer.98.3.737

11. Ismail, N. H., Karim, M. Z., \& Basri, B. H.(2016). Flood and Land Property Values. Asian Social Science, 12(5), 84-93. http:// dx.doi.org/10.5539/ass.v12n5p84

12. Ivanishin, V. V. (2010). Innovatsiine zabezpechennia onovlennia tekhnikotekhnolohichnoi bazy pidpryiemstv APK [Innovative provision of update of technicaltechnological base of agricultural enterprises]. Ekonomika APK -Agricultural Economy, 1, 128-134 (in Ukrainian).

13. Kachelmeier, S. J., \& Granof, M. H. (2008). Depreciation and capital investment decisions: experimental evidence in a governmental setting. Journal of Accounting and Public Policy, 12(4), 291-323. https:// doi.org/10.1016/02784254(93)90012-Z

14. Kalinowski, S. (2017). Operating Risk of Polish Public Companies - Sectoral Differences. Economics and Sociology, 10(1), 22-34. https://dx.doi.org/10.14254/2071789X.2017/10-1/2

15. Katan, L., Dobrovolska, O., \& Recio Espejo, J. M. (2018). Structural modeling of the financial support for the Ukrainian agrarian sector. Investment Management and Financial Innovations, 15(3), 199-211. http://doi.org/10.21511/ imfi.15(3).2018.17

16. Kharaishvili, E., Gechbaia, D., \& Mamuladze, G. (2018). Vegetable market: competitive advantages of Georgian product and competition challenges. Innovative Marketing, 14(3), 8-16. http://doi. org/10.21511/im.14(3).2018.02

17. Kolodiziev, O., Tyschenko, V., \& Azizova, K. (2017). Project finance risk management for public-private partnership. Investment Management and Financial Innovations, 14(4), 171-180. http://doi.org/10.21511/ imfi.14(4).2017.14

18. Kosnikov, S. N., Khaibullina, I.V., Ignatskaya, M.A., Bakharev, V.V., \& Pinchuk, V.N. (2017). Characteristic of economic indicators of reproduction of fixed capital. International Journal of Applied Business and Economic Research, 15(13), 243-253. Retrieved from http://serialsjournals.com/abstract/77834_ ch_25_f_-_085.pdf

19. Kuter, M. I. (2012). Vlyyanie amortyzatsyonnykh protsessov na formirovanie struktury i velichiny sobstvennogo kapitala [The effect of depreciation processes on the formation of the structure and value of equity]. Gosudarstvo $i$ region - State and region, 1(2), 3540 (in Russian). 
20. Kuter, M. I., Kuznetsov, A.V., \& Mamedov, R. I. (2008). Sovremennyy vzglyad na konceptsii amortizatsii [Modern view of depreciation concepts]. Ekonomicheskiy analiz: teoriia i praktika - Economic analysis: theory and practice, 24(129), 25-30 (in Russian).

21. Li, W. C. Y., \& Hall, B. H. (2016). Depreciation of Business R\&D Capital (NBER Working Paper 22473). National Bureau of Economic Research. Retrieved from https://www.nber.org/papers/w22473.pdf

22. Mayevsky, V. I., Malkov, S. Yu., \& Rubinstein, A. A. (2018). Analiz ekonomicheskoy dinamiki SSHA, SSSR i Rossii s pomoshchyu modeli PRV [Analysis of the economic dynamics of the USA, the USSR and Russia with the help of shifting mode of reproduction model]. Voprosy Ekonomiki - Economy issues, 7, 82-95 (in Russian). https://doi. org/10.32609/0042-8736-2018-782-95

23. Mukasheva, G., Zhakisheva, K., Yernazarova, A., Tazhikenova, S., Zhumanova, D., \& Kurmanova, G. (2018). Economic problems of the development of agroindustrial complex: Mechanism of solution. Journal of Applied Economic Sciences, 13(7), 2017-2030. Retrieved from https://www.researchgate.net/ publication/331497086_Economic_problems_of_the_development_of_agro-industrial_complex_Mechanism_of_solution

24. Nechaev, A., Barykina, Yu., \& Puchkova, N. (2017). Analysis of Articles of Fixed Assets Renewal of Russian Business Enterprises. In Proceedings of the International Conference on Trends of Technologies and Innovations in Economic and Social Studies (pp. 551-556). https://doi.org/10.2991/ ttiess-17.2017.90

25. Nurullin, AnasA., Subaeva, A. K., Nurullin, Aydar A., \& Aleksandrova, N. R. (2018). Management of reproduction of the fixed capital of the agricultural enterprises by method of economic and mathematical modeling. Journal of Social Sciences Research, 5, 265-271. Retrieved from https:// www.arpgweb.com/pdf-files/ spi5.61.265.271.pdf

26. Pistunov, I.M., \& Pistunova, K. I. (2007). Optymalni rishennia $v$ invectytsiinomu proektuvanni: navchalnyi posibnyk [Optimal solutions in injection design: a textbook] (108 p.). Dnipro: NGU (in Ukrainian).

27. Pronyaeva, L. I. (2016). Directions of increasing the role of depreciation as a source of reproducing fixed capital in agriculture. Studies on Russian Economic Development, 27(2), 197-202. https://doi.org/10. ccccc1134/S1075700716020118

28. Sigidov, Y. I., Rybyantseva, M. S., Adamenko, A. A., \& Yarushkina, E. A. (2016). Methodological aspects of depreciation as an economic category. International Journal of Economics and Financial, 6(1S), 88-95. Retrieved from https://www.econjournals. com/index.php/ijefi/article/ view/2359/pdf

29. Smith, A. (2014). The Wealth of Nations. In R. H. Campbell \& A. S. Skinner (Eds.), The Glasgow edition of the Works and Correspondence of Adam Smith (p. 678). Glasgow: The Glasgow University Press.

30. Smoliy, L., Zagorodniuk, O., \& Maliuga, L. (2017). Modelling of investment decisions on technical support of agricultural enterprises. Economic AnnalsXXI, 163(1-2), 79-84. Retrieved from https://pdfs.semanticscholar. org/fa19/f917c183f5d59a23bd317ca8493ae30b6fla.pdf

31. Sokolov, M. M. (2008). Yzmeneniya $\mathrm{v}$ amortizatsyonnoy politike kak osobaya forma nalogovogo vozdeystviya na razvitie ekonomiki [Changes in depreciation policy as a special form of tax impact on economic development]. Vse o nalogakh - All about taxes, 3, 23-29 (in Russian). Retrieved from https:// www.lawmix.ru/bux/52102

32. State Statistics Service of Ukraine. (2011). Statistical Yearbook for 2010. Kiev: Consultant Publishing
House LLC. Retrieved from http:// www.ukrstat.gov.ua/druk/st_sc/ SEU2010_e.zip

33. State Statistics Service of Ukraine. (2016). Statystychnyi biuleten "Osnovni zasoby Ukrainy"[Statistic Bulletin "The fixed assets of Ukraine"] (in Ukrainian). Retrieved from https://ukrstat. org/uk/druk/publicat/kat_u/publosn_zas_u.htm

34. State Statistics Service of Ukraine. (2018). Statistical Yearbook of Ukraine for 2017. Kiev: Consultant Publishing House LLC. Retrieved from http://www.ukrstat.gov.ua/ druk/publicat/kat_u/2018/zb/11/ zb_seu2017_e.pdf

35. Subaeva, A. K., \& Zamaidinov, A. A. (2016). Classification of agro-industrial complex technical provision effectiveness indexes. Journal of Economics and Economic Education Research, 17(4), 74-83. https://doi. org/10.29042/2018-2983-2987

36. Tronin, S. (2015). Technique of Determination of Optimum Volume and Structure of the Investment Capital of the Innovative Project. Asian Social Science, 11(8), 269-276. http:// dx.doi.org/10.5539/ass.v11n8p269

37. Yastremska, O. M., \& Yablonskaya, N. L. (2014). Investytsii: suchasne rozuminnia ta klasyfikatsiia [Investment: modern understanding and classification] Ekonomika rozvytku - Economics of development, 4, 116-121 (in Ukrainian). Retrieved from http://nbuv.gov.ua/UJRN/ ecro_2014_4_23

38. Yatsukh, O. (2018). Cognitive modeling of factors of influence on the processes of formation and reproduction of fixed assets of agricultural enterprises. Development Management, 16(4), 73-87. https://doi.org/10.21511/ dm.4(4).2018.07

39. Yevdokimov, Yu., Chygryn, O., Pimonenko, T., \& Lyulyov, O. (2018). Biogas as an alternative energy resource for Ukrainian companies: EU experience. Innovative Marketing, 14(2), 7-15. http://doi.org/10.21511/ im.14(2).2018.01 